\title{
ОСОБЛИВОСТІ САМОСТІЙНОЇ РОБОТИ МАЙБУТНІХ ПРОВІЗОРІВ 3 ДИСЦИПЛІНИ “ОРГАНІЧНА ХІМІЯ” В УМОВАХ БОЛОНСЬКОЇ СИСТЕМИ
}

\author{
I. В. Ніженковська, О. О. Глушаченко, О. І. Головченко \\ Національний медичний університет імені О. О. Богомольия, м. Київ
}

\section{PECULIARITES OF THE SELF-STUDYING FOR THE FUTURE PHARMACISTS AT THE CREDIT-MODULAR EDUCATIONAL SYSTEM}

\author{
I. V. Nizhenkovska, O. O. Hlushachenko, O. I. Holovchenko \\ National Medical University by O. O. Bohomolets, Kyiv
}

\begin{abstract}
У статті обгрунтовується необхідність удосконалення змісту самостійної роботи студентів та впровадження інноваційних технологій організації навчання з дисципліни “Органічна хімія".
\end{abstract}

The article adduces the necessity of improvement of the self-studying content and application of the innovational technologies for organization of studying process for organic chemistry.

Вступ. Реформування та розвиток освітньої системи в Україні, зокрема медичної та фармацевтичної [1-3], забезпечується Національною програмою “Освіта. Україна XXI сторіччя”, виконання якої повинно привести до реалізації системи безперервної освіти “через все життя". В сучасних умовах зростає необхідність безупинно розширювати своє сприйняття комплексності світу та формування інформаційного суспільства. Для того щоб знання отримали конкретний зв'язок з діями, необхідно постійно “навчати себе”. Ця система навчання спрямована на самостійну роботу людини. Тому самостійна робота студента повинна стати основною (пріоритетною) формою навчального процесу, що відповідає сучасним формам $i$ методам навчання Болонської освітньої системи.

Метою роботи є обгрунтування необхідності нових методів включення студентів у творчу діяльність та забезпечення відповідного акценту на їх самостійну роботу, набуття ними власного досвіду в процесі навчання.

Основна частина. Будь-який вид діяльності, який створює умови для зародження самостійної думки, пізнавальної активності студента, пов' язаний із самостійною роботою. Самостійна робота являє собою сукупність всієї самостійної діяльності студентів як у навчальній аудиторії, так і поза нею, в контакті 3 викладачем і в його відсутності, в створенні умов високої активності, самостійності і відповідальності за виконання самостійної роботи в ході будь-якої навчальної діяльності.
Перший напрямок - це збільшення ролі самостійної роботи в процесі аудиторних занять, що вимагає розробки методик і форм організації аудиторних занять, забезпечення високого рівня самостійності студентів і покращення якості підготовки.

Другий напрямок - підвищення активності студентів щодо всіх напрямків у позааудиторний час, що пов'язано з рядом труднощів: недостатнім інформаційним забезпеченням навчального процесу для ефективної організації самостійної роботи, неготовністю до самостійної роботи більшості студентів і викладачів в професійному і психологічному аспектах. Традиційно, виходячи із досвіду більшості вузів і окремих викладачів, самостійна робота реалізується:

- безпосередньо в процесі аудиторних занять, а саме: на лекціях, практичних і семінарських заняттях, при виконанні лабораторних робіт;

- в позааудиторний час - на консультаціях, при ліквідації заборгованості, при виконанні індивідуальних завдань (в контакті з викладачем);

- в бібліотеці, вдома, в гуртожитку, на кафедрі при виконанні студентом творчих задач.

Навчальний час, відведений для самостійної роботи студента, регламентується навчальними планами (типовим і робочим) i, згідно із положенням Закону України "Про вищу освіту", повинен становити не менше 1/3 та не більше 2/3 загального обсягу навчального часу, відведеного для вивчення конкретної навчальної дисципліни [4]. В навчальному плані 
підготовки фахівців освітньо-кваліфікаційного рівня “спеціаліст” кваліфікації “провізор” у вищих навчальних закладах України IV рівня акредитації є декілька циклів підготовки: гуманітарна та соціально-економічна, природничо-наукова, професійна та практична. На рисунку 1 наведені дані розподілу часу аудиторної та самостійної роботи між циклами підготовки відповідно до типових навчальних планів різних років.
Порівняльний аналіз навчальних планів різних років свідчить про те, що:

- спостерігається зростання кількості годин, зокрема самостійна робота студентів в 2003 році складала $42 \%$ від загального навчального завантаження, в 2009 році - 47 \%. Таким чином положення Болонського процесу орієнтують на надання більшої самостійності у вивченні навчальних дисциплін;
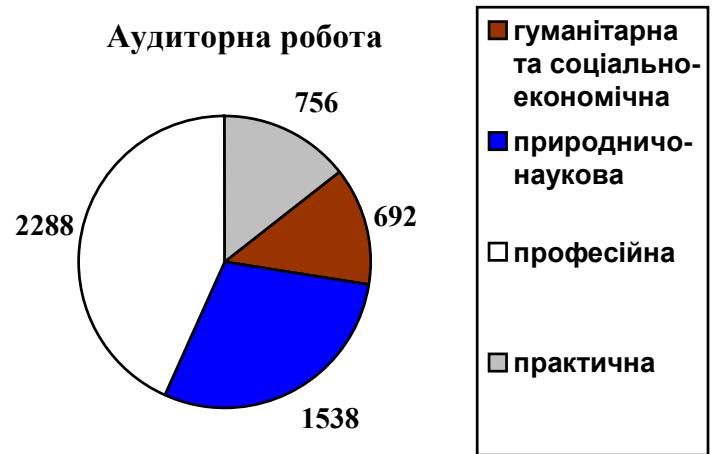

2003 рік

Аудиторна робота

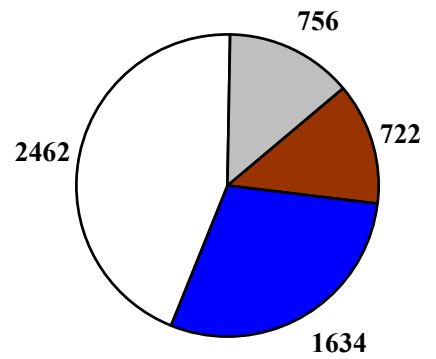

Аудиторна робота

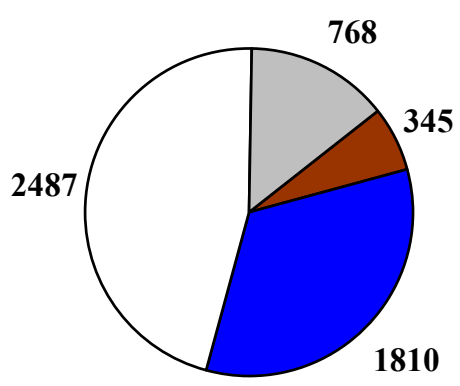

口гуманітарна та соціальноекономічна

Фприродничонаукова

$\square$ професійна

口практична

2007 рік

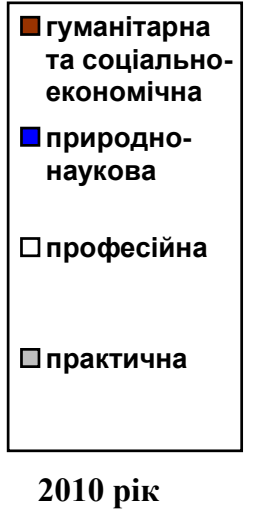

\section{Самостійна робота}

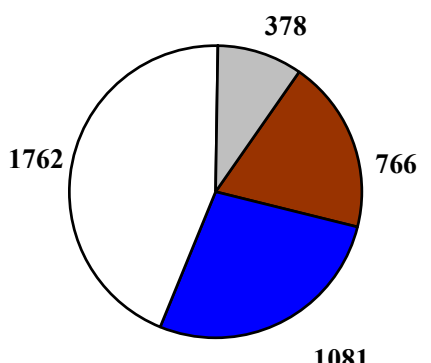

1081

Самостійна робота

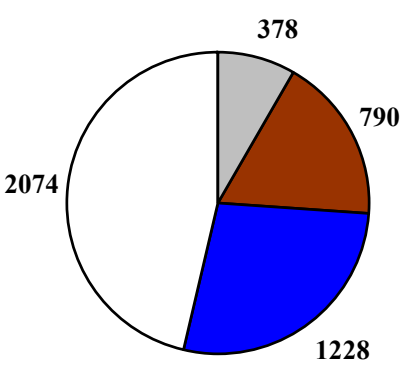

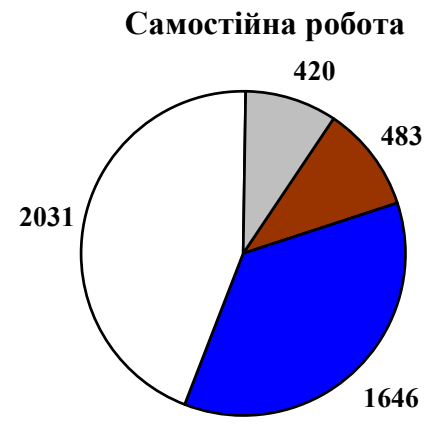

Puc. 1. Моніторинг кількості годин аудиторної та самостійної роботи студентів за циклами підготовки.

- змінюється розподіл часу аудиторної та самостійної роботи між циклами підготовки, набуває більшого значення природничо-наукова підготовка студентів.

На кафедрі біоорганічної, біологічної та фармацевтичної хімії Національного медичного університету викладається навчальна дисципліна “Органічна хімія” для студентів фармацевтичного факультету, спеціальність 7.110201 “Фармація”, денної форми навчання. Дисципліна входить до природничо-наукової підготовки студентів. Організація навчального процесу з вересня 2010 року здійснюється за кредитно-модульною системою відповідно до вимог Болонського процесу. 
Органічна хімія є однією з найважливіших дисциплін у системі вищої фармацевтичної освіти. Її вивчення надає студентові базову підготовку для оволодіння дисциплінами хімічного (аналітичною, біологічною, фізколоїдною; фармацевтичною, токсикологічною хімією, фармакогнозією); медико-біологічного (патологією, фармакологією); технологічного (аптечною і заводською технологією ліків, технологією парфумерно-косметичних засобів) профілів.

Головним завданням органічної хімії як фундаментальної дисципліни є забезпечення наукового підходу до вирішення проблем, пов'язаних 3 фармацевтичним та хіміко-токсикологічним аналізом. При викладанні органічної хімії слід приділяти увагу не тільки теоретичній підготовці студентів, але й різнобічним практичним навичкам і вмінням у проведенні хімічного експерименту. Оскільки 95 \% лікарських засобів мають органічну будову, то систематичне вивчення закономірностей хімічної поведінки органічних сполук у взаємозв’ язку з їх будовою і формування на цій основі творчого хімічного мислення необхідне для успішного освоєння профільних дисциплін, наприклад фармацевтичної хімії, а також для практичної діяльності.

Видами навчальних занять для даної навчальної дисципліни згідно з навчальним планом є: а) лекції; б) лабораторні заняття; в) самостійна робота студентів (СРС); г) контрольні заходи. Як свідчать дані таблиці 1, кількість годин з органічної хімії значно збільшилась в основному за рахунок самостійної роботи студентів.

Таблиця 1. Розподіл годин у межах дисципліни (відповідно до типових навчальних планів різних років)

\begin{tabular}{|c|c|c|c|c|c|c|}
\hline $\begin{array}{c}\text { Навчальні } \\
\text { програми }\end{array}$ & Кредит & Всього & $\begin{array}{c}\text { Аудиторні } \\
\text { години }\end{array}$ & Лекції & $\begin{array}{c}\text { Практичні } \\
\text { заняття }\end{array}$ & $\begin{array}{c}\text { Самостійна робота } \\
\text { студентів (СРС) }\end{array}$ \\
\hline 2003 & 5 & 270 & 180 & 36 & 144 & $90(33 \%)$ \\
2007 & 9 & 324 & 192 & 42 & 150 & $132(41 \%)$ \\
2009 & 9 & 324 & 180 & 30 & 150 & $144(44 \%)$ \\
\hline
\end{tabular}

Вивчення органічної хімії, згідно з навчальним планом, затвердженим у 2010 році, розпочинається на 2му році навчання (III та IV семестри). Дана дисципліна “Органічна хімія” структурована на 2 модулі, які, в свою чергу, поділяються на 5 змістових модулів. На вивчення дисципліни відведено 9 кредитів. Загальна кількість годин складає 324 години, самостійна робота студентів складає 44 \% від загального навантаження.

При оцінюванні поточної навчальної діяльності вага теми в балах визначається діленням 120 балів (за поточний контроль) на кількість тем навчальних за- нять в модулі; остання тема (підсумковий модульний контроль) не враховується.

Відповідно до Листа МОЗ України від 21.01.2008 p. № 08.01-22/65 та згідно з рішенням Вченої ради НМУ від 14.02.2008 р. протокол № 6, при оцінюванні засвоювання кожної теми модуля студенту виставляються оцінки за чотирибальною (традиційною) шкалою. При цьому враховуються усі види робіт, передбачені методичною розробкою для вивчення теми.

Виставлені за традиційною шкалою оцінки конвертуються у бали залежно від кількостей у модулі, як приклад, таким чином:

\begin{tabular}{|c|c|c|c|c|c|c|c|c|}
\hline “5” & 3 & 5 & 6 & 9 & 10 & 12 & 15 & 18 \\
\hline "4" & 2,5 & 4 & 5 & 7 & 8 & 10 & 12 & 15 \\
\hline "3" & 2 & 3 & 4 & 5 & 6 & 8 & 9 & 12 \\
\hline "2" & 0,75 & 1 & 1,35 & 1,75 & 2 & 2,75 & 3 & 4 \\
\hline
\end{tabular}

Вага кожної теми в межах одного модуля має бути однаковою, але може бути різною для різних модулів однієї дисципліни і визначається кількістю тем у модулі.

Наприклад: МОДУЛЬ 1. Основи будови органічних сполук. Вуглеводні (алкани, циклоалкани, алкени, алкадієни, алкіни, арени) та їх функціональні похідні (галогено-, нітрогено- гідроксипохідні вуглеводнів. Альдегіди. Кетони). Кількість тем в модулі-17. Тому вага кожної теми в межах першого модуля становить - 7 балів (5 - традиційна), 6 балів (4), 3 бали (4). Незадовільна оцінка - 1,3 бала.
Мінімальна кількість балів, яку повинен набрати студент при вивченні модуля, для допуску до підсумкового модульного контролю вираховується шляхом множення кількості балів, що відповідають оцінці “'3”, на кількість тем у модулі, тобто складає 68 бал \pm в. Максимальна кількість балів, яку може набрати студент за поточну діяльність при вивченні модуля, вираховується шляхом множення кількості балів, що відповідають оцінці “5”, на кількість тем у модулі (119 балів) 3 додаванням балів за індивідуальне завдання студента. Таким чином, кількість балів, яка залишається на виконання індивідуального завдання, мінімальна (1 
бал), тобто студенти не мають мотивації до виконання такого виду самостійної роботи, про що свідчать дані соціологічних досліджень (рис. 2).

3 метою вивчення особливостей самостійної роботи в умовах кредитно-модульної системи в Національному медичному університеті імені О. О. Богомольця проводились соціологічні дослідження з питань організації самостійної роботи студентів в умовах кредитно-модульної системи та традиційної форми навчання. Думка студентів з цього приводу вивчалась методом анкетування. До анкети були внесені питання, які висвітлювали дві сторони самостійної роботи студента при вивченні органічної та фармацевтичної хімії: це як розподіляється час, який витрачається на самостійну роботу та які джерела застосовувались сту- дентом під час виконання самостійної роботи. В опитуванні брали участь студенти 2-5 курсів фармацевтичного факультету, які навчаються за спеціальністю “Фармація”, і умовно були поділені на дві групи. Перша група-студенти-відмінники, яка включає не тільки тих студентів, які мають лише відмінні оцінки, але і тих, що є високо вмотивованими у навчанні. Друга студенти, які мають середній бал “3” (за традиційною системою оцінювання знань).

Згідно з положенням про організацію навчального процесу в кредитно-модульній системі, самостійна робота студентів охоплює різни види робіт [5], які залежно від успішності студентів розподіляються порізному. Результати соціологічних досліджень представлені на рисунках 2-3.

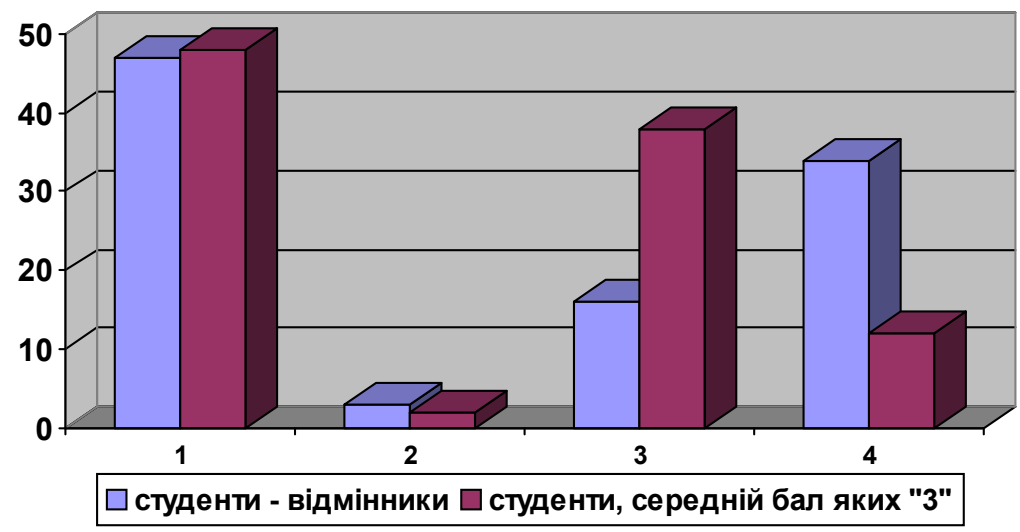

Puc. 2. Розподіл часу на різні види самостійної роботи студента.

1. Підготовка до аудиторних занять (лекцій, практичних, семінарських, лабораторних тощо); 2. Виконання індивідуальних завдань з навчальної дисципліни протягом семестру; робота над окремими темами навчальних дисциплін відповідно до навчально-тематичних планів; 3. Підготовка до всіх видів контрольних випробувань, у тому числі до курсових, модульних і комплексних контрольних робіт; 4. Робота в студентських наукових гуртках, семінарах; участь у роботі факультативів, спецсемінарів; участь у науковій i науково-методичній роботі кафедр, факультетів; участь у наукових і науково-практичних конференціях, семінарах, конкурсах, олімпіадах.

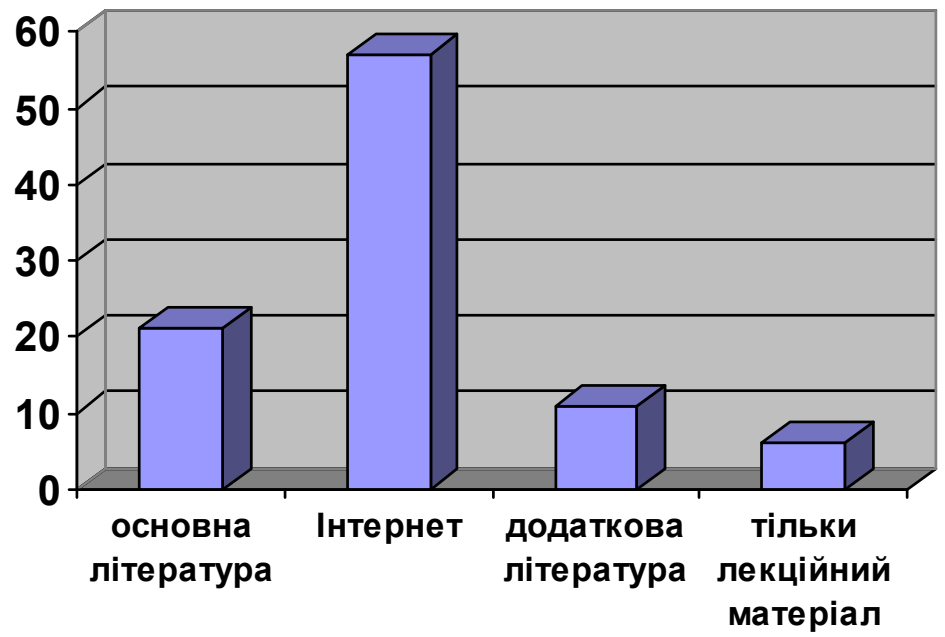

Puc. 3. Джерела, якими користуються студенти при виконанні самостійної роботи. 
У ході опитування виявилось, що "студентивідмінники" майже рівномірно розподіляють свій час на різні види самостійної роботи порівняно із студентами, середній бал яких за традиційною системою оцінювання знань складає “3”. 3'ясувалось також, що при самостійній підготовці перевагу надають глобальній системі Internet.

Запровадження КМСОНП у систему підготовки провізорів потребує перебудови системи викладання [6], а саме перенесення акценту на самостійну роботу студентів, де головним завданням викладача "навчити навчатися”. Донедавна така робота студентів обмежувалась лише самостійним опрацюванням окремих тем 3 навчальної дисципліни. Отриманий досвід викладання органічної хімії на кафедрі біоорганічної, біологічної та фармацевтичної хімії, а також досвід Національного фармацевтичного університету (м. Харків) [7] за КМСОНП дозволяє внести корективи до оцінювання поточної навчальної діяльності. Наприклад: максимальна кількість балів, яку студент може набрати за поточний контроль, -108 (кількість тем у модулі 18), а за виконання різних видів індивідуальних завдань - 12 балів. Бали за індивідуальні завдання нараховуються студентові лише при успішному їх виконанні та захисті. Вони додаються до суми балів, набраних студентом за поточну навчальну діяльність.

Виконання індивідуальної роботи майбутнього провізора можливе при наявності серйозної мотивації. Мо-

\section{Література}

1. Сучасний розвиток вищої медичної та фармацевтичної освіти й проблемні питання забезпечення якісної підготовки лікарів і провізорів / М. В. Банчук, О. П. Волосовець, I. I. Фещенко [та ін.] // Медична овіта. -2007.-№ 2. - С. 5-13.

2. Біоетика як навчальна дисципліна у вищій медичній школі України / М. В. Банчук, О. П. Волосовець, І. С. Вітенко, І. В. Мельник // Медична овіта. - 2007. - № 3. - С. 8-10.

3. Сучасний розвиток вищої медичної та фармацевтичної освіти та проблемні питання забезпечення якісної підготовки лікарів і провізорів / М. В. Банчук, О. П. Волосовець, I. I. Фещенко [та ін.] // Впровадження засад Болонської системи освіти : український та зарубіжний досвід : матеріали Всеукраїнської навчально-наукової конференції. -Тернопіль : ТДМУ, 2007.- С. 3-12.

4. 1. Закон України “Про вищу освіту” № 2984-III, із змінами від 19 січня 2010 р. [Електронний ресурс]. - Режим дос- тивація студентів зумовлює формування короткострокових та довгострокових цілей. Вагомим мотивуючим чинником є підготовка до успішної професійної діяльності. На кафедрі заплановані такі види індивідуальної роботи, які вчать їх логічно мислити, аргументувати та допомагають виявити творчий потенціал студента, дозволяють перевести студента із пасивного отримувача знань в активного їх творця, який вміє формулювати проблему, проаналізувати шляхи їі вирішення та знайти правильний результат. Студентам пропонуються розв'язування складних схем перетворень та підготовка окремих тем дисципліни у вигляді мультимедійної презентації.

Висновки. Досвід впровадження кредитно-модульної системи організації навчального процесу 3 дисципліни “Органічна хімія” на кафедрі біоорганічної, біологічної та фармацевтичної хімії і результати проведених соціологічних досліджень виявили необхідність нових підходів в організації самостійної роботи студентів:

1. В самостійній роботі студентів значну увагу слід приділяти елементам дослідження під керівництвом і наглядом досвідчених викладачів.

2. Для більш ефективної організації самостійної роботи студентів $є$ доцільним створення спеціальних навчальних кімнат з можливістю роботи в Internet.

3. Для розвитку творчих здібностей студентів запровадити як одну з форм контролю виконання самостійної роботи проведення міні-конференцій.

тупу до журналу : http://zakon.rada.gov.ua/cgi-bin/laws/ main.cgi?nreg=1060-12

5. Тимчасове положення про організацію навчального процесу в кредитно-модульній системі підготовки фахівців (затверджено наказом Міністерства освіти і науки України від 23 січня 2004 р. № 48).

6. Москаленко В. Ф. Досвід навчання студентів за європейською кредитно-трансферною системою в НМУ імені О. О. Богомольця як основа для підвищення якості медичної освіти / В. Ф. Москаленко, О. П. Яворовський, Л. І. Остапюк // Медична овіта. - 2010. - № 2. - С. 60-63.

7. Результати впровадження кредитно-модульної системи організації навчального процесу в Національному фармацевтичному університеті / В. П. Черних, І. С. Гриценко, С. В. Огарь, Л. М. Вінник // Медична освіта. -2010. - № 2.C. 69-72. 